\title{
PEMBERITAAN MEDIA ASING MENGENAI HUKUM CAMBUK GAY DI ACEH
}

\author{
Reni Juliani \\ Program Studi Komunikasi Fakultas Ilmu Sosial dan Ilmu Politik \\ Universitas Teuku Umar Meulaboh \\ Email : renijuliani@utu.ac.id
}

\begin{abstract}
This study aims to analyze why there are pro and cons of foreign media in the news of the whipping of gay couples in Aceh. The method used in this research is qualitative method. The subjects of this research are some sources of news from media. Data collection techniques were conducted with library research and documentation. The results obtained after conducting library research and documentation are two issues that make the media pro and cons against the news of this case. The first is the issue of caning and human right law, and the second is the gay issue of minorities. Pro-gay and anti-Islam stigma are built on the issue of human right violstions and caning punishmant that considered other forms of torture in various reports.
\end{abstract}

Keywords: News, Foreign Media, Caning Law, and Gay.

\section{PENDAHULUAN}

\section{Latar Belakang Masalah}

Penerapan Syari'at Islam di wilayah Aceh merupakan cita-cita rakyat Aceh sejak dahulu. Penerapan ini telah melalui proses panjang yang diajukan untuk pembentukkannya mulai dari pemerintahan Soekarno. Penerapan Syari'at Islam tersebut baru diaminkan pada masa SBY. Penerapan Syari'at Islam di Aceh juga merupakan salah satu perjanjian dalam MoU Helsinki. Di dalam Nota Kesepahaman antara Pemerintahan Republik Indonesia dan Gerakan Aceh Merdeka menjelaskan bahwa Qanun Aceh akan disusun kembali untuk Aceh dengan menghormati tradisi sejarah dan adat istiadat rakyat Aceh serta mencerminkan kebutuhan hukum terkini Aceh. Hal tersebut menegaskan bahwa Aceh berhak menyusun Qanun sesuai keadaan dan kondisi Aceh.

Penerapan Syari'at Islam di Aceh telah berlangsung selama beberapa tahun. Namun hal ini tidak menjadikan semua masyarakat dan elemen-elemen di dalam masyarakat menyetujui segala kebijakan pemerintah tersebut. Penerapan Syari'at Islam masih memicu pro dan kontra dari berbagai kalangan. Terlebih lagi dengan hukuman yang didera terdakwa pelanggar syari'ah seperti hukum cambuk. Hukum cambuk masih dianggap bentuk pelanggaran HAM oleh sebagian kalangan. Pihak yang kurang setuju dengan ditetapkannya hukum cambuk sebagai sebuah hukuman syari'ah menganggap bahwa hukuman cambuk tidak manusiawi dan melanggar hakhak sebagai manusia.

Pro dan Kontra hukuman cambuk semakin memanas saat dilaksanakannya hukum cambuk terhadap pasangan gay yang melakukan pelanggaran Syari'at Islam. Pasangan Gay ini dicambuk pada tanggal 23 mei 2017 lalu dan menjadi isu hangat yang diangkat oleh berbagai media baik media lokal maupun media asing. Ada dua isu yang menjadi focus dalam kasus ini yaitu isu hukum cambuk dan pasangan gay. 
Pasangan gay yang diadili oleh Mahkamah Syari'ah tersebut dikenakan Pasal 63 ayat 1 Qanun Nomor 6 Tahun 2014 tentang Hukum Jinayat yang berbunyi "Setiap orang yang dengan sengaja melakukan Jarimah Liwath (zina homoseksual) diancam dengan 'Uqubat Ta'zir (cambuk) paling banyak 100 (seratus) kali cambuk atau denda paling banyak 1.000 (seribu) gram emas murni atau penjara paling lama 100 (seratus) bulan." Pasal tersebut menjelaskan bahwa hukuman yang terima adalah 100 kali cambuk. Akan tetapi pasangan gay yang melakukan tindakan asusila tersebut hanya didera hukuman 85 kali cambukan.

Selain di Aceh, Negara Bagian Kelantan, Malaysia, juga telah mengatur tentang larangan liwath (homoseksual) dalam pengertian sosomi, baik yang dilakukan antar-laki-laki dengan perempuan lain yang bukan istrinta. Pasal 16 dan Pasal 17 The Hudud Bill of Kelantan, Menentukan (Djubaedah, 2010:273-274):

"Liwat is an offence consisting of carnal intercourse between a male and another male or between a male and a female other than his wife, performed against the order ofnature. That is the anus."

(Liwat adalah kejahatan melakukan hubungan badan (pesertubuh) antara sesama laki-laki atau antara laki-laki dengan perempuan lain yang bukan istrinya, dilakukan berlawanan dengan yang seharusnya, yaitu melalui anus [dubur]).

"Whoever commits liwat shal be punished with the same punishment prescribed for zina,"

(Barang siapa melakukan liwat akan dijatuhi hukuman sebagaimana hukuman yang ditentukan atas zina).

Kasus pencambukan pasangan gay ini merupakan kasus pertama setelah ditetapkannya Qanun Jinayat di tahun 2015. Hal ini menjadi penyebab mengapa media asing sangat menyoroti kasus ini. Salah satu media asing yang meliput pelaksanaan hukuman tersebut adalah BBC. BBC bahkan membuat video wawancara pendapat LGBT (lesbian, gay, biseksual, dan transgender) di Aceh. Video BBC tersebut seakan menegaskan bahwa pasangan gay merupakan korban dan penerapan syariat Islam di Aceh dinilai tidak relevan.

Fenomena di atas merupakan konteks penelitian ini, sekaligus menjadi alasan mengapa penelitian ini harus dibuat. Penelitian ini berjudul "Pemberitaan Media Asing Mengenai Hukum Cambuk Gay Di Aceh"

Berdasarkan latar belakang di atas, maka dapat disimpulkan yang menjadi asalah Utama yang ingin dikaji dalam penelitian ini adalah mengapa terjadi pro dan kontra media asing dalam pemberitaan hukum cambuk pasangan gay di Aceh? Oleh sebab itu yang menjadi tujuan umum dari penelitian ini yaitu untuk menganalisis mengapa terjadi pro dan kontra media asing dalam pemberitaan hukum cambuk pasangan gay di Aceh.

Penelitian ini diharapkan dapat memberikan kontribusi bagi media khususnya media asing yang ingin memberitakan suatu isu yang sensitif dan menjadikan masukan bagi pemerintah dalam menegakkan hukum yang sudah sepatutnya dipatuhi oleh seluruh masyarakat. Di samping itu, penelitian ini diharapkan dapat memberikan pemahaman kepada pembaca mengenai telah ditetapkan dan dijalankan sebuah hukum yang mengatur tentang Jarimah Liwath (zina yang dilakukan kaum Gay) di Aceh.

\section{KAJIAN LITERATUR}

\section{Sejarah Syari’at Islam di Aceh}

Sebelum Masehi, Aceh banyak dilalu oleh pedangang-pedangang dari berbagai negara. 
Dikarenakan letak wilayahnya yang strategis, Aceh menjadi pusat perdagangan Asia Tenggara. Pedagang Timur Tengah sebelum melanjutkan perjalananya ke Cina, singgah di Aceh terlebih dahulu (Djalil, 2010:181). Hal inilah yang menjadi asal mula masuknya Islam ke wilayah Aceh. Dajlil (2010:181) menjelaskan bahwa:

"Abad VI. Abad ini abad kelahiran Islam, pada abad inilah Aceh menjadi wilayah pertama di Nusantara ini menerima Islam, para sejarawan pada umumnya menyebutkan bahwa masuknya melalui daerah Peurlak/Pase. Abad XII. Setelah melalui proses sejarah yang panjang, Aceh menjelma menjadi sebuah kerajaan Islam, yang kemudian berkembang menjadi sebuah kerajaan yang maju. Abad XIV. Perkembangan kerajaan Aceh ditandai dengan dikenalnya Aceh sebagai daerah pusat perkembangan Islam ke seluruh wilayah Asia Tenggara."

Ketika Aceh menang dalam perang melawan Portugis dan mengusir mereka dari tanah Aceh. Kerajaan Aceh mulai berdiri dengan dikukuhkannya Sultan Alaidin Ali Mughaiyat Syah sebagai Sultan pertama Kerajaan Aceh Darussalam dengan ibukota negara Banda Aceh. Dalam bukunya yang berjudul "Aceh dalam Perang Mempertahankan Proklamasi Kemerdekaan 19451949 dan Peranan Teuku Hamid Azwar Sebagai Pejuang,” Jakobi (2004:17) juga menyebutkan bahwa:

"Berdirinya Kerajaan Islam Besar pada masa tersebut sekaligus mendudukkan Aceh Darussalam menjadi salah satu Kerajaan Islam Besar yang masuk dalam deretan "Lima Besar Islam". Pada masanya, Lima Besar Islam ini menjalin kerja sama ekonomi, politik, militer, dan kebudayaan. Lima Besar Kerajaan Islam tersebut adalah:

a. Kerajaan Islam Turki Usmaniyah yang berpusat di Istambul.

b. Kerajaan Islam Maroko di Afrika Utara.

c. Kerajaan Islam Isfahan di Timur Tengah.

d. Kerajaan Islam Agra di Anak Benua India.

e. Kerajaan Aceh Darussalam di Asia Tenggara.”

Setelah diplokamirkan kemerdekaan Indonesia pada tahun 1945, masyarakat Aceh ingin wilayahnya dibentuk peraturan yang bersumber dari agama Islam. pembentukan peraturan mengenai Syari'at Islam tidak sepenuhnya diaminkan oleh pemerintah. Walaupun pada saat itu izin mengenai pembentukan Mahkamah Syari'ah telah diberikan oleh Gubernur Sumatera Utara melalui surat kawat No.189 Tanggal 13 Januari 1947, namun peraturan yang diizinkan hanya berupa peraturan mengenai peratura-peraturan dalam bidang kekeluargaan seperti perkara nafkah, perkawinan, perceraian, harta bersama, warisan, hak pengampunan anak dan sebagainya (Amal dan Panggabean, 2004:20).

Walaupun Mahkamah Syari'ah telah terbentuk namun keberadaannya kembali dikaburkan oleh pemerintah pada Tahun 1950. Seperti yang dijelaskan oleh Amal dan Panggabean (2004:20) bahwa Mahkamah Syari'ah dan semua pengadilan swapraja disatukan dalam satu payung Pengadilan Negeri. Hal ini terjadi setelah dikeluarkannya UU Darurat No.1 Tahun 1950. Dikarenakan semangat dan impian besar masyarakat Aceh untuk membentuk wilayah yang berasaskan Islam, Pemerintah di daerah Aceh dan seluruh lini masyarakat mendesak pemerintah untuk memberikan status Mahkamah Syari'at yang jelas dan pasti. Desakan tersebut tidak pernah berhenti dan terus diperjuangkan oleh masyarakat Aceh sehingga akhirnya pemerintah mengeluarkan Peraturan Pemerintah No.29 Tahun 1957 mengenai pembentukan pengadilan agama di seluruh Aceh, termasuk susunan dan kewenangannya. Namu Pemerintah kembali membuat masyarakat Aceh kecewa. Peraturan yang dikeluarkannya tidak serta merta menjadikan hakim-hakim Pengadilan Agama bisa leluasa dalam memberikan putusannya. Keputusan-keputusan mereka dibatasi. Mereka hanya diberi wewenang dalam putusan bidang 
kekeluargaan dan warisan, dan hal tersebut baru bisa dijalankan setelah Pengadilan Agama mengaminkannya.

Pemerintah telah mengeluarkan berbagai peraturan pemerintah mengenai pembentukan Mahkamah Syari'ah. Seperti yang telah dijelaskan di atas. Pembentukan peraturan mengenai Syari'at Islam mulai dari Undang-undang Darurat sampai Peraturan Pemerintah telah ditetapkan. Namun kebijakan pemerintah tersebut terkesan tidak sepenuh hati. Peraturan yang dikeluarkan pemerintah tidak menyentuh seluruh peraturan yang ingin ditegakkan oleh masyarakat.

Pada masa Gubernur Tgk. Daud Beureueh, Pemerintah memberikan harapan yang sangat besar kepada Gubernur dan masyarakat Aceh mengenai Syari'at Islam. Soekarno berjanji untuk mengizinkan Aceh sebagai wilayah yang memberlakukan Syari'at Islam. Namun janji tersebut dilanggarkan. Seperti yang diceritakan Abubakar (2002: 26) bahwa:

"Soekarno berulang kali berjanji akan memberikan keluasan kepada Aceh untuk memberlakukan Syari'at Islam. Tetapi janji tersebut hanya berbentuk lisan, tidak memiliki kekuatan hukum kuat padahal Tgk. Daud Beureueh meminta agar janji itu dituliskan, namun Soekarno menjawab sambil berlinang air mata berkata 'Apakah Kakanda Daud Beureueh tidak mempercayai saya lagi?' Mendengar ungkapan Soekarno, hati Daud Beureueh melunak dan tidak laki menuntuk janji tertulis.

Pada Tahun 1959, Pemerintah Pusat mengeluarkan Keputusan untuk menyelesaikan "Peristiwa Aceh" tersebut. Keputusan tersebut adalah Keputusan Perdana Menteri Republik Indonesia Nomor I/Missi Tahun 1959 dimana keputusan tersebut memberikan Aceh gelar Daerah Istimewa. Keistimewaan tersebut berupa bidang agama, pendidikan dan adat (Zamzani, 1970: 322). Sedangkan izin pelaksanaan Syari'at Islam baru diberikan pada masa reformasi. Dedi Sumardi M.Ag (Bantasyam dan Siddiq, 2009:41) menjelaskan bahwa pelaksanaan Syari'at Islam ini sesuai dengan UU No.44 Tahun 1999 tentang Keistimewaan Aceh. Selain berasaskan UU No.44 Tahun 1999, izin pelaksanaan Syari'at Islam juga berdasarkan UU No.18 Tahun 2001. Prof. Dr. Syahrizal Abbas (Bantasyam dan Siddiq, 2009:63) menjelaskan mengenai pelaksanaan Syari'at Islam di Aceh bahwa:

"Pelaksanaan Syari'at Islam di Aceh yang dibawa oleh kedua undang-undang yaitu UU No.44 Tahun 1999 dan UU No.11 Tahun 2006, membawa semangat formulasi ajaran Islam melalui aturan formal negara yaitu Qanun Aceh. Melalui Qanun inilah berbagai aturan Syari'at Islam dapat ditegakkan dalam kehidupan bermasyarakat dan berbangsa di Aceh. Persoalan yang muncul adalah bagaimana merumuskan materi Qanun yang kuat secara filosofis dan tidak kering dari semangat sosiologis dari ketentuan Syari'at."

Sedangkan Qanun Jinayat sendiri baru disahkan pada tahun 2014. Qanun Jinayat No. 6 Tahun 2014 tentang Hukum Jinayat ini mulai berlaku pada Tanggal 23 Oktober 2015, setahun setelah disahkannya. Hukum Jinayat ini merupakan hukum pidana yang memuat ketetuan hukuman cambuk dan rajam. Juga menegaskan pada tindakan yang melanggar Syari'at seperti zina, maisir, dan banyak lagi termasuk liwath (homoseksual). Dalam Qanun Jinayat No.6 tahun 2014 Pasal 63 menyebutkan perihal liwath yang berbunyi sebagai berikut:

1. Setiap Orang yang dengan sengaja melakukan Jarimah Liwath diancam dengan 'Uqubat Ta'zir paling banyak 100 (seratus) kali cambuk atau denda paling banyak 1.000 (seribu) gram emas murni atau penjara paling lama 100 (seratus) bulan.

2. Setiap Orang yang mengulangi perbuatan sebagaimana dimaksud pada ayat (1) diancam dengan 'Uqubat Ta'zir cambuk 100 (seratus) kali dan dapat ditambah dengan denda 
paling banyak 120 (seratus dua puluh) gram emas murni dan/atau penjara paling lama 12 (dua belas) bulan

3. Setiap Orang yang melakukan Liwath dengan anak, selain diancam dengan 'Uqubat Ta'zir sebagaimana dimaksud pada ayat (1) dapat ditambah dengan cambuk paling banyak 100 (seratus) kali atau denda paling banyak 1.000 (seribu) gram emas murni atau penjara paling lama 100 (seratus) bulan.

\section{Media dan Peranananya} ini, yaitu:

McQuail (1987:3) mengemukakan sejumlah peran yang dimainkan media massa selama

1. Industri pencipta lapangan kerja, barang dan jasa serta menghidupkan industri lain utamanya dalam periklanan/promosi.

2. Sumber kekuatan-alat kontrol, manajemen, dan inovasi masyarakat.

3. Lokasi (forum) untuk menampilkan peristiwa masyarakat.

4. Wahana pengembangan kebudayaan-tatacara, mode, gaya hidup, dan norma.

5. Sumber dominan bukan saja bagi pencipta citra individu, tetapi juga bagi kelompok, dan masyarakat.

Sebuah Film yang merupakan salah satu seri dari film James Bond yang berjudul "Tomorrow Never Dies" ini menceritakan tentang bahaya apabila media berhasil memonopoli "kebenaran", selain itu media bisa membuat konspirasi besar di dalam pemberitaannya sehingga media mampu mempengaruhi dan mengendalikan publik. Apabila hal ini terjadi, dunia sepenuhnya akan ada di tangan media. Rizki (Hasyim, dkk, 2013:125) menjelaskan:

"Digambarkan di awal film bagaimana Carver-Raja Media Dunia yang mampu menjatuhkan pemerintahan dengan sebuah berita-sedang dalam perayaan atas peluncuran satelit barunya dalam jaringan Grup Media Carver. Satelit ini tidak hanya dimanfaatkan untuk kepentingan medianya saja, tapi juga menjadi salah satu alat perang yang digunakan untuk memanipulasi informasi termasuk informasi militer negara-negara dunia. Di akhir pidatonya saat peluncuran satelit yang akan mampu menjangkau seluruh umat manusia di muka bumi ini-kecuali Cina yang menolak menyiarkannya-dia berjanji untuk memberikan berita tanpa ketakutan dan tendensi, berjuang untuk kebaikan dunia, melawan ketidakadilan, ketidakpedulian, memerangi ketidakmanusiaan. Tapi apa dinyana, Carver bukan orang yang jujur dan menepati kata-katanya. Dia juga adalah seorang penjahat yang baru saja membuat aksi kekacauan di Laut Cina Selatan yang memantik konfrontasi pihak Inggris dan Cina. Carver memiliko koran, majalah, buku, film, TV, radio, online, dan dengan kekuasaannya dia mampu meletupkan sebuah isu sehingga menjadi 'besar' dengan sokongan medianya"

Peranan media sangat besar bagi kehidupan dunia. Oleh sebab itu sudah selayaknya dan sepatutnya media harus menjadi sumber kepercayaan masyarakat mengenai informasi sehingga kehidupan masyarakat menjadi lebih baik lagi sehingga masyarakat dapat berkaca pada media. Media menjadi watch dog (anjing penjaga) bagi pemerintah dan masyarakat. Di Indonesia sendiri, begitu tinggi posisi media. Media dijadikan salah satu pilar demokrasi. Media merupakan pilar ke-empatnya. Dengan kata lain, demokrasi ada apabila ditegakkannya media atau pers. Syam (2016: 28) menyebutkan bahwa:

"Disebabkan anjing penjaga mempunyai kekuatan untuk menggonggong apabila terdapat kesalahan, maka terkadang ada kecenderungan anjing penjaga di bawah 
peliharaan para pemodal, atau kalau diinterpretasi ulang, anjing penjaga yang sudah dipelihara para majikan pemilik modal. Kalau hal ini dapat terjadi, maka sangat sulit untuk diharapkan dapat menjalankan fungsinya sebagai anjing pengawas yang selalu mengawasi terhadap para yang membuat kesalahan dalam masyarakat baik dalam aspek politik, ekonomi maupun sosial. Pers yang demikian, dalam berfungsi sebagai watch dog dalam kenyataan sudah diikat kakinya dan dijinakkan gonggongannya. Betapapun, anjing biasanya sangat paham dengan tuannya. Ia tak akan menggonggong apalagi mengginggit tuannya, walaupun mungkin tuannya melakukan tindakan yang mencurigakan. I hanya menggonggomg orang asing yang tidak begitu dikenalnya. Ini terjadi mengingat pers sudah terjadi tumpang tindih dalam kepemilikan. Pers sudah mulai dimiliki oleh penguasa yang juga sekaligus terjun sebagai politisi. Sebagian dari mereka sadar dengan kekuatan media yang dapat dimanfaatkan untuk meraih keuntungan politis. Dalam keadaan demikian, sangat sulit bisa diharapkan media massa dapat menjadi anjing penjaga yang galak terhadap kekuasaan."

\section{Kronologi Kasus Pasangan Gay}

Dalam media berita online baranewsaceh.com, Iyan (2017) menjelaskan kronologis penggrebekan pasangan Gay di Aceh. Kasus ini bermula dari kecurigaan warga atas gerak gerik MT, pria asal Sumatera Utara dan MH, pria asal Jeunieb Kabupaten Bireun. Kecurigaan ini lebih kepada MT yang berperilaku seperti wanita (waria). Pada awalnya, warga tidak begitu curiga terhadap keduanya. Dikarenakan kerap bergonta-ganti pasangan dan selalu mengajak teman prianya bermalam, kecurigan masyarakat semakin menjadi sehingga diambil keputusan untuk melakukan penggerebekan ke rumah indekos di Dusun Silang Desa Rukoh, Darussalam, Kota Banda Aceh. Dari penggerebekan tersebut didapati kedua pria tersebut terlanjang dan beberapa barang bukti berhasil diamankan. Barang bukti tersebut antara lain:

1. My Baby ( Pelicin)

2. Celana dalam 2

3. Kondom Baru 3

4 Kondom yg sudah terpakai 1

5 Tisu 2 lbr

6. HP Xiaomi 1

7 Dompet 2

Selanjutnya kedua pelaku dan Barang bukti di serahkan ke Komandan Operasi Wilayatul Hisbah untuk diproses. Setelah MT dan MH mengaku bersalah dan dinilai terbukti melakukan perbuatan yang melanggar ketentuan Qanun Nomor 6 Tahun 2014 tentang Hukum Jinayat. Hakim memutuskan hukuman untuk pasangan Gay ini. Keduanya dijatuhi hukuman cambuk sebanyak 85 kali.

\section{Pemberitaan Media Asing Terkait Hukum Cambuk Gay di Aceh}

\section{The Sun (Media Berita Inggris)}

Dalam pemberitaannya dengan judul "caned for the crowd: two gay men whipped in front of large crowds taking selfies after being caught in bed together in indonesia," The Sun menyebutkan bahwa hukum cambuk merupakan barbaric punishment. The Sun memberikan penjelasan pada gambar yang diliputnya dengan kalimat "Thousands filled the square to watch the barbaric punishment" (Charlton, 2017). 


\section{Belfast Telegraph (Media Berita Inggris)}

Two men caned in Indonesia for gay sex merupakan judul besar dari berita yang dipublikasikan oleh Belfast Telegraph (belfasttelegraph.co.uk, 2017) yang membahas mengenai kejadian kasus pecambukan pasangan gay di Aceh. Di dalam pemberitaannya, media berita Inggris ini terkesan kontra terhadap keputusan Pemerintahan Provinsi Aceh yang mengadili kedua pasangan gay yang melanggar syari'at Islam dengan hukuman cambuk sebanyak 85 kali. Belfast Telegraph menyebutkan bahwa hukuman cambuk tersebut adalah sebuah bentuk penyiksaan abad pertengahan. Pernyataan tersebut berbunyi "The punishment was denounced by rights advocates as "medieval torture" and intensifies an anti-gay backlash in the world's most populous Muslim country."

\section{Transkrip Video BBC (Media Berita Inggris)}

Pada tanggal 23 Mei 2017, sebuah situs berita online bbc.com merilis video berjudul "Pencambukan gay di Aceh berlangsung dalam sorakan". Video berdurasi lebih dari 1 menit tersebut dibuat oleh Rebecca Henschke dan Oki Budhi, wartawatan BBC Indonesia yang melihat secara langsung proses hukum cambuk pasangan gay di Banda Aceh. Berikut transkrip video (Henschke dan Budhi, 2017) yang beredar di media sosial:

Mereka (pasangan gay) dipermalukan di depan publik dengan 82 kali cambukan karena didakwa melakukan hubungan sesama jenis. Mereka adalah gay pertama yang ditindak dengan hukum syariah di aceh. Lalu bagaimana kaum LGBT di Aceh menanggapinya?

Aktivis gay di Aceh : Tentu sangat takut karena itu bisa saja terjadi sama saya. Untungnya pasangan saya memang tidak di sini. Saya merasa tidak berdosa karena itu adalah urusan privasi saya. Dengan agama saya dan dengan Tuhan saya. Selama saya tidak menyakiti orang, tidak memaki-maki orang, tidak memfitnah orang, tidak mengambil hak orang, saya merasa itu semua tidak dosa.

\section{Tapi Wali Kota Banda Aceh tegas mengusir LGBT.}

Wali Kota Banda Aceh : Saya ingin menyelamatkan generasi ini. Kita bayangkan apabila dunia ini menjadi sesama jenis semua dan penyakit itu akan hadir, timbul dan sebagainya. Kita tidak membenci orangnya, yang tidak kita senangi adalah perbuatannya.

Video tersebut sempat beredar di banyak media sosial sehingga menjadi pembicaraan khusus. Hal ini dikarenakan video ini memperlihatkan wawancara secara khusus kelompok LGBT di Aceh yang mengatakan keberatan dengan keputusan pemerintah Aceh untuk mencambuk pasangan gay yang ditangkap oleh Wilayatul Hisbah. Mereka menganggap hal tersebut merupakan upaya merenggut hak-hak mereka selaku manusia yang ingin diperlakukan sama seperti manusia lainnya.

Selain wawancara dengan kelompok LGBT Aceh, di akhir video singkat tersebut ada cuplikan sekilas wawancara Wali Kota Banda Aceh. Di dalam video tersebut Wali Kota menjelaskan kegelisahannya akan genereasi muda berikutnya. Beliau menjelaskan bahwa beliau ingin menghindari generasi mudanya akan penyakit yang timbul karena hubungan sesama jenis.

Video BBC ini terkesan kontra terhadap keputusan pemerintah Aceh. Dilihat dari katakata yang digunaka seperti kata "mengusir" untuk menggambarkan bahwa Wali Kota Banda Aceh 
membenci kaum Gay dan tidak ingin ada kaum Gay yang tinggal di wilayahnya. Padahal ditekankan oleh Wali Kota di semua wawancara yang dilakukannya bahwa beliau tidak membenci orangnya tapi perbuatannya.

\section{Pro dan Kontra Media Asing terhadap Pemberitaan Hukum Cambuk Pasangan Gay di Aceh}

Dari hasil yang telah dipaparkan di atas dapat kita lihat bahwa yang menjadikan media asing pro dan kontra terhadap pemberitaan huku cambuk pasangan gay di Aceh dikarenakan 2 isu sensitif yang berkaitan dengan kasus tersebut. Isu tersebut antara lain adalah:

\section{Hukum Cambuk dan HAM}

Alyasa' Abu Bakar (Yani, 2011: 181) penulis artikel "Syariat Islam jangan Bertentangan dengan HAM", Alyasa' menyatakan bahwa Ia setuju dengan hukuman cambuk, menurutnya "Semua hukuman adalah derita, yang menurut filosof Eropa, penderitaan paling berat adalah kehilangan kemerdekaan. Logikanya karena hak asasi paling dasar adalah kebebasan, maka hukuman cambuk yang diterapkan adalah yang lebih ringan dan yang agak jauh dari pelanggaran HAM."

Segala peraturan Syari'at Islam di Aceh telah disesuaikan dengan hukum Islam yang menjadi landasannya, hukum yang berlaku di Indonesia dan juga hukum Hak Asasi Manusia. Hal tersebut agar penerapan Syari'at Islam tidak bertentangan dengan Hukum-hukum lainnya yang ada di Indonesia (Yani, 2011:204). Yani (2011:204) juga menambahkan bahwa:

"Bukan hanya di Aceh, penerapan hukum Jinayat dalam Islam didukung konsep HAM yang telah disahkan dalam Deklarsi Universal Hak-hak Asasi Manusia Menurut Islam (DIUHR) 1981 dan Deklarasi Kairo (CDHRI) 1990_yang menyatakan bahwa penerapan syariat Islam di dunia dapat disesuaikan dengan penafsiran fiqh berbagai mazhab yang ada dalam Islam menurut kondisi dan situasi umat Islam berada, (tak terkecuali di Aceh-Indonesia). Menurut Hukum Islam dan konsep HAM Islam, menghukum orang yang bersalah bukan bertujuan untuk menyiksa mereka secara tidak manusiawi dan merendahkan martabatnya. Namun merupakan balasan atas kesalahan yang ia lakukan, di samping merupakan salah satu cara taubah (permohonan ampunan/penyesalan dari dosanya), bila dilakukan dengan suka rela. Tujuan Hukum Islam adalah untuk mencegah kriminalitas-(kesalahan) yang samadilakukan oleh umat Islam yang lain."

Prof. Syahrizal, staf pengajar IAIN Ar Raniry Banda Aceh (Bantasyam dan Siddiq, 2009: 140) menyatakan bahwa: "Terkait dengan urusan hak asasi manusia, penerapan hukum Islam di Aceh dipandang oleh sebagian kalangan di Aceh tidak melanggar HAM. Penerapan hukum Syari'at Islam bukan untuk menghukum orang, akan tetapi pada prinsipnya justru melindungi, menjaga keamanan dan ketertiban semua orang."

Seperti hasil wawancara Warsidi (2017), wartawan tempo.co dengan berbagai tokoh menjelaskan bahwa mereka sangat mendukung pelaksanaan hukum cambuk terhadap pasangan gay tersebut. Menurut mereka hukuman tersebut tidak melanggar HAM dan sudah sesuai dengan aturan-aturan di dalam qanun. Berikut kutipan wawancara mereka:

"Kasus cambuk untuk gay adalah yang pertama kali di Aceh, sejak hukum cambuk diberlakukan pada 2003 silam.Hukum cambuk sendiri diatur dalam Qanun Hukum Jinayat, yang juga mengacu kepada Al Quran dan hadist. Masyarakat luar mungkin merasa asing, karena di luar tidak diatur tentang hukuman yang seperti ini. Kalau ada yang bilang melanggar HAM, saya mengajak semua pihak bisa saling 
menghargai proses hukuman cambuk, karena yang dilakukan tersebut sesuai dengan aturan dalam hukum' Kata Yusnardi. Sementara itu, Tgk Abdul Gani Isa dari dari Majelis Permusyawaratan Ulama (MPU) Kota Banda Aceh mengatakan bahwa 'hukuman cambuk berdasarkan azas pembelajaran yang terkandung dalam Qanun Aceh, persuasif dan mendidik semua orang. Tidak bertentangan dengan HAM. Hukuman juga dilaksanakan secara terbuka dan melalui proses pengadilan. Bahkan saat prosesi hukuman cambuk dilakukan, mereka didampingi jaksa dan tim medis, sesuai dengan aturan yang dibakukan dalam qanun."'

Beda halnya bila kita membicarakan Konsep Hak Asasi Manusia (HAM) PBB yang memiliki perbedaan yang signifikan dengan aturan-aturan Jinayah. Walaupun mempuyai perbedaan yang besar, hadirnya HAM PBB memberikan peranan penting di dalam kehidupan manusia. Kesadaran akan hak-hak dasar seorang manusia meningkat. Manusia berhak bebas dari rasa takut, intimidasi dari pihak lain, penyiksaan dan segala bentuk hak yang merampas kemerdekaan seorang manusia (Yani, 2011:205)

\section{Gay sebagai Kaum Minoritas}

Gay merupaka kaum minoritas di Indonesia. Kaum ini termasuk dalam komunitas LGBT (Lesbi, Gay, Biseks dan TransGender). Akhir-akhir ini, isu LGBT merupakan isu yang tengah panas-panasnya. Berbagai pihak ada yang menolak dan ada juga pihak yang menjadi pembela. Banyak kalangan yang menolak berasal dari ormas Islam yang menuntuk agar tidak terulangnya dosa-dosa kaum nabi Luth di muka bumi ini. Sedangkan pembela kaum LBGT kebanyak berasal dari aktivis-aktivis LBGT, HAM dan juga dari pemerintah negara-negara yang mendukung adanya komunitas ini. Nurdin (2016) menjelaskan bahwa:

"Dalam kondisi minoritas, kaum gay memposisikan diri sebagai orang-orang yang dizalimi. Berharap perhatian dan dihargai. Kata mereka, keluarga dan masyarakat telah memperlakukan mereka tidak adil. Datanglah pembelaan dari aktivis HAM (Hak Asasi Manusia). Para aktivis kemanusiaan yang tidak mengenal fitrah manusia. Mereka membela siapa saja, kecuali umat Islam. Islam tetap konsisten, kebenaran tidak diukur oleh jumlah. Yang banyak bisa jadi benar, bisa pula berlaku zalim. Yang sedikit bisa saja berpegang teguh dengan kebenaran, dan belum tentu pula selalu benar. Kebenaran adalah apa yang sesuai dengan Alquran dan Sunnah Rasulullah."

Fitriana (2016) mengaitkan LGBT dan media. Ia menerangkan bahwa media massa sangat berperan dalam penyebaran isu-isu mengenai LGBT. Media mempunyai andil besar dalam pencitraan kaum minoritas ini.Media bahkan bisa mempengaruhi seseorang baik dari segi kognis, afeksi maupun konatifnya. Fitriana (2016) menjelaskan bahwa:

"Media massa dapat membentuk pencitraan tertentu dari suatu peristiwa atau suatu kelompok dan dipahami sebagai kebenaran atau kesalahan yang umum dalam masyarakat. Simbol-simbol atau istilah yang terus menerus diulang menciptakan citra tersendiri tentang sesuatu di mata masyarakat. Pencitraan yang sudah begitu melekat dalam benak masyarakat ini kemudian berkembang menjadi stereotype atau biasa kita sebut sebagai judjing (lebeling). Pada mulanya media massa menggambarkan dan memberi stereotipe sehingga isu yang berkembang di masyarakat Indonesia dan dunia adalah mengenai kaum LGBT yang dianggap menyimpang dari norma, kenyataannya saat ini media massa tak lagi seperti itu, media massa justru mengekspos kaum-kaum tersebut dari sisi positif mereka. Kaum ini dipandang sebagai kaum yang "benar" bukan lagi menyimpang. Media tidak pernah memberitakan sisi negatife mereka 
karena media tidak memiliki hak menjelekan atau mengeksploitasi kaum tertentu. “

\section{PENUTUP}

Dari apa yang telah dijelaskan maka dapat disimpulkan bahwa, ada 2 isu yang menimbulkan pro dan kontra media dalam pemberitaan hukum cambuk pasangan gay di Aceh, yaitu: yang pertama adalah isu hukum cambuk dan ham, dan yang kedua adalah isu gay kaum minoritas.

Mengingat kasus pro dan kontra media dalam pemberitaan hukum cambuk pasangan gay di Aceh, Penulis ingin menegaskan bahwa peraturan tentang pelanggaran Syari'at Islam telah ada di Aceh. Pelaksanaan Syari'at Islam di Aceh berbeda dengan negara-negara lainnya. Hal ini dikarenakan peraturan yang dibuat disesuaikan dengan kondisi wilayah dan masyarakat setempat. Pro dan Kontra dalam pemberitaan media bisa saja terjadi. Namun dalam pemberitaan haruslah berimbang sehingga tidak terkesan berita yang dibuat hanya untuk kepentingan sebagian kalangan semata.

Setelah melakukan penelitian mengenai pemberitaan media asing mengenai kasus hukum cambuk pasangan gay, maka penulis memberikan beberapa saran antara lain:

1. Penulis mengharapkan pemerintah akan lebih terbuka lagi terhadap media khususya media asing dan apabila terjadi perbedaan pendapat di dalam pemberitaan media, sudah sepatutnya Pemerintah mengklarifikasikan pemberitaan tersebut.

2. Penulis mengharapkan apabila memang ingin Syari'at ini dijalankan secara kaffah, maka ada baiknya pemerintah meneliti bagaimana Perjanjian Madinah yang telah disepakati Internasional itu dibuat sehingga Pemerintah Provinsi Aceh bisa mencontoh langkah-langkah yang dilakukan Pemerintah Madinah.

3. Penulis mengharapkan kepada kaum LGBT untuk menghormati hukum yang telah ada di Aceh. Karena penetapan Syari'at Islam merupakan impian masyarakat Aceh dari dulu. Oleh sebab itu dimana bumi dipijak, disitulah langit dijunjung.

4. Penulis juga menyarankan kepada masyarakat untuk tidak menghukum kaum LGBT secara massal, karena hukum dan punishment telah ada. Jadi selaku masyarakat bila menemui kesalahan da nada pelanggaran hukum untuk menghubungi pihak yang berwenang. Jangan main hakim sendiri.

\section{DAFTAR RUJUKAN}

Abubakar, Al Yasa'. (2002). Pelaksanaan Syari'at Islam: Sejarah dan Prospek. Dalam Safwan Idris, dkk. Syari'at Islam di Wilayah Syari'at: Pernak-pernik Islam di Nanggroe Aceh Darussalam. Banda Aceh: Dinas Syari'at Islam NAD.

Amal, Taufik Adnan dan Panggabean, Samsu Rizal. (2004). Politik Syari'at Islam: Dari Indonesia hingga Nigeria. Jakarta: Pustaka Alvabet.

Bantasyam, Saifuddin dan Siddiq, Muhammad (ed). (2009). Aceh Madani dalam Wacana: Format Ideal Implementasi Syari'at Islam di Aceh. Banda Aceh: Aceh Justice Resource Center (AJRC).

Djalil, Basiq. (2010). Peradilan Agama di Indonesia. Jakarta: Kencana Prenada Media Group.

Djubaedah, Neng. (2010). Perzinaan: Dalam Peraturan Perundang-undangan di Indonesia 
Ditinjau dari Hukum Islam. Jakarta: Kencana

Hasyim, Ansari, dkk. (2013). Wajah Syari'at Islam di Media. Banda Aceh: Aliansi Jurnalis Independen.

Jakobi, A.K. (2004). Aceh dalam Perang Mempertahankan Proklamasi Kemerdekaan 1945-1949 dan Peranan Teuku Hamid Azwar Sebagai Pejuang. Jakarta: Grametika Pustaka Utama.

McQuail, McQuail. (1987). Mass Communication Theory (Teori Komunikasi Massa). Jakarta: Erlangga.

Syam, Hamdani M. (2016). Jurnalisme Damai: Memahami Pemberitaan di Daerah Konflik. Yogyakarta: Samudra Biru (Anggota IKAPI)

Yani, Muhammad. (2011). Pelaksanaan Hukum Jinayat di Aceh dalam Perspektif Hukum dan HAM: Studi Qanun Nomor 12, 13, dan 14 Tahun 2003. Banten: Isdar Press.

\section{Penelitian dan Perundang-undangan}

Qanun Aceh No. 6 tahun 2014 tentang Hukum Jinayah.

\section{Website dan Berita}

Belfast Telegraph Digital: Two Men Caned in Indonesia for Gay Sex. Diakses Tanggal 05 Juni 2017, dari http://www.belfasttelegraph.co.uk/news/world-news/two-men-caned-inindonesia-for-gay-sex-35744936.html edisi 23/05/2017

Charlton, Corey. (2017). CANED FOR THE CROWD: Two gay men WHIPPED in front of large crowds taking selfies after being caught in bed together in Indonesia. Diakses Tanggal 20 Juni 2017, dari https://www.thesun.co.uk/news/3631226/indonesia-gay-menwhipped-crowds-caught-in-bed-together/

Fitriana, Lia. (2016). Ketika Kaum Minoritas Menjadi Sorotan Media Massa. Diakses Tanggal 03 Juli 2017, dari http://www.kompasiana.com/liafitriana/ketika-kaum-minoritasmenjadi-sorotan-media-massa_54f94f6da3331178178b4974

Hadi, Nurfitri. (2016). Pelajaran dari Kisah Nabi Luth Ketika Kaum Gay Mayoritas. Diakses Tanggal 21 Juni 2017, dari http://kisahmuslim.com/5428-pelajaran-dari-kisah-nabi-luthketika-kaum-gay-mayoritas.html

Henschke, Rebecca dan Budho, Oki. (2017). Pencambukan gay di Aceh berlangsung dalam sorakan. Diakses Tanggal 03 Juni 2017, dari www.bbc.com/indonesia/indonesia40009560

Iyan. (2017). Berhubungan Intim Sesama Jenis, Dua Pria Diamankan Warga Darussalam Banda Aceh. Diakses Tanggal 22 Juni 2017, dari http://baranewsaceh.co/2017/03/29/berhubungan-intim-sesama-jenis-dua-priadiamankan-warga-darussalam-banda-aceh/ 
Nurdin, Ihan (ed). (2016). Pelajaran dari Kisan Nabi Luth Ketika Kaum Gay Mayoritas. Diakses Tanggal 30 Juni 2017, dari http://portalsatu.com/read/oase/pelajaran-dari-kisah-nabiluth-ketika-kaum-gay-mayoritas-8700

Warsidi, Adi. (2017). Kepala Polisi Syariah Banda Aceh: Hukuman Cambuk Tak Langgar HAM. Diakses Tanggal 5 Juni 2017, dari https://nasional.tempo.co/read/news/2017/05/23/063878011/kepala-polisi-syariahbanda-aceh-hukuman-cambuk-tak-langgar-ham 